\title{
Simple UV Spectrophotometric Assay of Metronidazole
}

\author{
Safila Naveed, Fatima Qamar \\ Faculty of Pharmacy, Jinnah University for Women Karachi, Karachi, Pakistan \\ Email: ${ }^{*}$ afila117@yahoo.com, fatimamudassar2009@hotmail.com
}

Received 5 June 2014; revised 15 July 2014; accepted 28 August 2014

Copyright (C) 2014 by authors and OALib.

This work is licensed under the Creative Commons Attribution International License (CC BY).

http://creativecommons.org/licenses/by/4.0/

(c) (i) Open Access

\begin{abstract}
Metronidazole is a derivative of benzimidazole. It is being used widely for the treatment of amoebiasis. An efficient, simple and least time consuming spectrophotometric method for the assay of metronidazole has been developed. Comparison of assay of three different brands of metroni-dazole has also been available in public medical stores of Karachi, Pakistan. The assay is based on the ultraviolet $U V$ absorbance maxima at about $340 \mathrm{~nm}$ wavelength of metronidazole using water as solvent. A sample of drug was dissolved in water to produce a solution containing metronidazole. Similarly, a sample of ground tablets of different brands were dissolved in water and various dilutions were made. The absorbance of sample preparation was measured at $340 \mathbf{n m}$ against the solvent blank and the assay was determined by comparing with the absorbance of available brand. The method can be applied for the routine QC quantitation of metronidazole in tablet formulation actively.
\end{abstract}

\section{Keywords}

Metronidazole, Assay, UV Spectrophotometry

Subject Areas: Inorganic Chemistry, Medicinal Chemistry

\section{Introduction}

Metronidazole (Figure 1) has been used for the treatment of infections for more than 45 years and is still in use for the treatment of amoebiasis, giardiasis and trichomoniasis. Anaerobic bacterial infections caused by, Fusobacteria, Bacteroides species and Clostridia are best treated by metronidazole therapy [1]. Metronidazole is a nitroimidazole derivative. It is a recommended treatment during pregnancy for infections with bacterial vaginosis and Trichomonas vaginalis [2]. The metronidazole treatment protocols commonly employed are three times per day for three to five days [3]. It is typically administered to adults in doses of $250 \mathrm{mg}$ three times a day for five to seven days and $15 \mathrm{mg} / \mathrm{kg}$ three times a day for five to seven days in children. From all around the world,

*Corresponding author. 


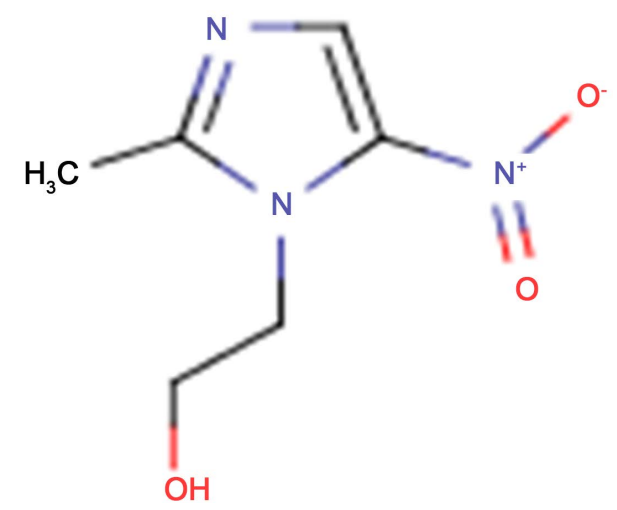

Figure 1. Structure of metronidazole.

therapeutic failure of metronidazole and the drug for giardiasis in humans, have been increasingly reported [4]. It is prescribed commonly for a wide range of non-parasitic infectious diseases. The chances of the development of clinically drug-resistant strains of Helicobacter pylori HP, leading cause of gastro intestinal GI cancer may increase by overusing metronidazole for the treatment of parasitic infections. According to previous reports metronidazole toxicity may induce several neurologic side effects, including ataxic gait, peripheral neuropathy, dysarthria, encephalopathy and seizures [5]. We have already performed these types of assay for different drugs for the measurement of active substances [6]-[12].

\section{Methodology}

UV visible 1601 Shimadzu double beam spectrophotometer was used to spectram measurement Water was used as a solvent for performing assay.

\subsection{Wavelength Selection}

About $100 \mathrm{ppm}$ of metronidazole solution was accurately prepared in water. This solution was scanned in the $200-400 \mathrm{~nm}$ UV region. The wavelength maxima $\left(\lambda_{\max }\right)$ was observed at $340 \mathrm{~nm}$ and this wavelength was adopted for absorbance measurement.

\subsection{Standard Stock Solution}

Accurately weighed $10 \mathrm{mg}$ of metronidazole standard was transferred to a volumetric flask and add sufficient water to produce $100 \mathrm{ml}$.

\subsection{Sample Preparation}

The three different brands (flagyl, gramex, metrozine) were purchased from different medical store located in Karachi, Pakistan. All tablets of each brand have same batch number and were labeled to conatin metonidazole $400 \mathrm{mg}$ per tablet. All the three brands have 5 year shelf life.

The serial number as an identification of purchased brands is given in Table 1. 20 tablets of three different brand of metronidazole from the marketed sample were weighed and crushed uniformly with the help of a mortar and pestle. By calculating the average weighed sample powder equivalent to $10 \mathrm{mg}$ of metronidazole was transferred into a volumetric flask containing $10 \mathrm{ml}$ water. The solutions were sonicated for about 5 min and than make up volume up to $100 \mathrm{ml}$ with water.

\section{Procedure}

After preparation of standard and tablet solutions, strength of solution $100 \mathrm{ppm}$ in $100 \mathrm{ml}$ absorbance of the sample preparation and standard preparation in $1 \mathrm{~cm}$ cell at the wavelength of maximum absorbance at about $340 \mathrm{~nm}$, using a spectrophotometer, using the blank solution. Calculate the quantity in $\mathrm{mg}$, of metronidazole per tablet. 


\section{Results and Discussion}

Results are given in Tables 2-4. Pharmaceutical assay of metronidazole was carried out on different brands using spectrophotometer. Table 1 shows brand name, average weight and amount use for preparation of $100 \mathrm{ppm}$ solution, absorbance and \% assay of different brands. Table 2 shows the descriptive statistic of drugs with SD and standard error.

Test of hypothesis i.e. ANOVA and multiple comparison of different brands of metronidazole are given in Table 3. It shows highly significant difference of $\mathrm{p}=0.005$ and $\mathrm{F}$ value is 8697.899 of all brands with $\mathrm{df} 2,12$ within and between groups. Table 4 shows multiple comparison of all brands with each other and the results show highly significant $p$ values, $p=0.000$ in each case. This proposed method for assay of commercially available metronidazole tablet formulation is very simple, economical, accurate, least time consuming and rapid. It

\begin{tabular}{cccccc}
\hline \multicolumn{2}{l}{ Table 1. \% assay of different brands of Metronidazole. } \\
\hline Brand Name & Serial no. & Average wt of tablet $\mathbf{~ m g}$ & Wt for $\mathbf{1 0 0} \mathbf{~ p p m}$ & Absorbance at $\mathbf{3 4 0} \mathbf{~ n m}$ & \% assay \\
\hline Flagyl & MET-1 & 511.8 & 12.7 & 2.40 & $100 \%$ \\
Gramex & MET-2 & 750 & 18 & 2.850 & $118.75 \%$ \\
Metrozine & MET-3 & 742 & 18 & 2.772 & $115.5 \%$ \\
\hline
\end{tabular}

Table 2. Descriptive statistics of different brands of Metronidazole.

\begin{tabular}{|c|c|c|c|c|c|c|c|c|}
\hline & \multirow{2}{*}{$\mathrm{N}$} & \multirow{2}{*}{ Mean } & \multirow{2}{*}{ Std. Deviation } & \multirow{2}{*}{ Std. Error } & \multicolumn{2}{|c|}{ 95\% Confidence Interval for Mean } & \multirow{2}{*}{ Minimum } & \multirow{2}{*}{ Maximum } \\
\hline & & & & & Lower Bound & Upper Bound & & \\
\hline MET-1 & 5 & 2.4060 & 0.00548 & 0.00245 & 2.3992 & 2.4128 & 2.40 & 2.41 \\
\hline MET-2 & 5 & 2.8460 & 0.00548 & 0.00245 & 2.8392 & 2.8528 & 2.84 & 2.85 \\
\hline MET-3 & 5 & 2.7664 & 0.00590 & 0.00264 & 2.7591 & 2.7737 & 2.76 & 2.77 \\
\hline Total & 15 & 2.6728 & 0.19822 & 0.05118 & 2.5630 & 2.7826 & 2.40 & 2.85 \\
\hline
\end{tabular}

Table 3. ANOVA.

\begin{tabular}{cccccc}
\hline & Sum of Squares & df & Mean Square & F & Sig. \\
\hline Between Groups & 0.550 & 2 & 0.275 & 8697.899 & 0.000 \\
Within Groups & 0.000 & 12 & 0.000 & & \\
Total & 0.550 & 14 & & & \\
\hline
\end{tabular}

\begin{tabular}{|c|c|c|c|c|c|c|c|}
\hline \multicolumn{8}{|c|}{ Dependent Variable: absorbance } \\
\hline & \multirow{2}{*}{ (I) Brands } & \multirow{2}{*}{ (J) Brands } & \multirow{2}{*}{ Mean Difference (I - J) } & \multirow{2}{*}{ Std. Error } & \multirow{2}{*}{ Sig. } & \multicolumn{2}{|c|}{ 95\% Confidence Interval } \\
\hline & & & & & & Lower Bound & Upper Bound \\
\hline \multirow{6}{*}{ Tukey HSD } & \multirow{2}{*}{ MET-1 } & MET-2 & $-0.44000^{*}$ & 0.00356 & 0.000 & -0.4495 & -0.4305 \\
\hline & & MET-3 & $-0.36040^{*}$ & 0.00356 & 0.000 & -0.3699 & -0.3509 \\
\hline & \multirow{2}{*}{ MET-2 } & MET-1 & $0.44000^{*}$ & 0.00356 & 0.000 & 0.4305 & 0.4495 \\
\hline & & MET-3 & $0.07960^{*}$ & 0.00356 & 0.000 & 0.0701 & 0.0891 \\
\hline & \multirow{2}{*}{ MET-3 } & MET-1 & $0.36040^{*}$ & 0.00356 & 0.000 & 0.3509 & 0.3699 \\
\hline & & MET-2 & $-0.07960^{*}$ & 0.00356 & 0.000 & -0.0891 & -0.0701 \\
\hline
\end{tabular}

${ }^{*}$ The mean difference is significant at the 0.05 level. 
can be used for routine QC quality control analysis in the API, and tablet formulation.

\section{References}

[1] Löfmark, S., Edlund, C. and Nord, C.E. (2010) Metronidazole Is Still the Drug of Choice for Treatment of Anaerobic Infections. Clinical Infectious Diseases, 50, S16-S23. http://dx.doi.org/10.1086/647939

[2] Centers for Disease Control and Prevention (2010) Guidelines for Treatment of Sexually Transmitted Diseases. MMWR Morbidity and Mortality Weekly Report, 47, 8-10. http://www.cdc.gov/std/treatment/2010/default.htm

[3] Jokipii, L. and Jokipii, A.M.M. (1978) Comparison of Four Dosage Schedules in the Treatment of Giardiasis with Metronidazole. Infection, 6, 92-94. http://dx.doi.org/10.1007/BF01642166

[4] Wright, J.M., Dunn, L.A., Upcroft, P. and Upcroft, J.A. (2003) Efficacy of Antigiardial Drugs. Expert Opinion on Drug Safety, 2, 529-541. http://dx.doi.org/10.1517/14740338.2.6.529

[5] Selgrad, M., Kandulski, A. and Malfertheiner, P. (2009) Helicobacter pylori: Diagnosis and Treatment. Current Opinion in Gastroenterology, 25, 549-556. http://dx.doi.org/10.1097/MOG.0b013e32833159f2

[6] Dilshad, H., Naveed, S. and Naqvi, B. (2013) Assay of New Formulations of Isosorbide Mononitrate by Using UV Spectrophotometer: BPJ0000115. World Research Journal of Medicine, 1, 1-2.

[7] Naveed, S., Sultana, N., Arayne, M.S. and Dilshad, H. (2014) A New HPLC Method for the Assay of Levofloxacin and Its Application in Drug-Metal Interaction Studies. Journal of Scientific and Innovative Research, 3, 91-96. www.jsirjournal.com

[8] Dilshad, H. and Naveed, S. (2014) Manufacturing of New Formulations of Isosorbide Mononitrate by Dry Granulation Method and Their Comparitive Evaluation with Brands Available in the Market. IRJP, 5, 168-171

[9] Naveed, S., Fatima, Q. and Ghulam, S. (2014) Percentage Assay of Metformin in Different Medium Using UV-Spectrophotometer BPJ0000130. World Research Journal of Organic Chemistry, 2, 2320-5679,

[10] Naveed, S. (2014) Simple UV Spectrophotometric Assay of Atorvastatin API Formulation and Their Comparative Study. Global Journal of Medical Research, 14, 35-38.

[11] Dilshad, H., Naveed, S. and Waheed, N. (2014) Comparitive Study of Four Different Brands of Captopril Available in Karachi. IRJP, 5, 374-377. http://www.irjponline.com/admin/php/uploads/2170 pdf.pdf

[12] Naveed, S. and Qamar, F. (2014) Comparative Study of Different Brands of Alprazolam. Global Journal of Medical Research, 14, 25-28. 